Published by LPMP Imperium

Journal homepage: https:/ / ejournal.imperiuminstitute.org/ index.php/ BERDAYA

\title{
Pelatihan Pemasaran Produk Dengan Pemanfaatan Teknologi Informasi Secara O nline
}

\author{
Roy Budiharjo, Suri Mahrani \\ Fakultas Ekonomi dan Bisnis, Universitas Mercu Buana
}

\begin{abstract}
The purpose of this community service is to provide understanding to participants, especially M SMEs, on how to market products online by utilizing technology for free. This training will introduce the products offered in the long term compared to conventional means that can offer in the short term.

This training is given to people in South M eruya village who want to become entrepreneurs through the use of technology to improve product marketing efficiency. The results of this training can be used to increase competitiveness and public knowledge about marketing in today's digital era.
\end{abstract}

\author{
Keywords \\ Online Marketing, \\ MSMES
}

BERDAYA : Jurnal

Pendidikan dan Pengabdian

Kepada M asyarakat

Vol 2, N 0.3, D esember 2020,

pp. 119 - 124

elSSN 2721-6381

\section{Article History}

Received 20 Aug 2020 / Accepted 05 Dec 2020 / First Published: 30 Dec 2020

\section{To cite this article}

Budiharjo, R., Anasta, L., \& Mahrani, S. (2020). Pelatihan Pemasaran Produk Dengan Pemanfaatan Teknologi Informasi Secara Online. BERDAYA : Jurnal Pendidikan D an Pengabdian Kepada M asyarakat, 2(3), 119 - 124.

DOI: $10.36407 /$ berdaya.v2i3.273

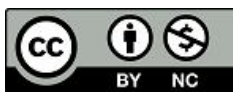

(C) 2020. This open access article is distributed under a Creative Commons Attribution (CC-BY-NC) 4.0 license 


\section{ABSTRAK}

Tujuan dari pengabdian masyarakat ini adalah untuk memberikan pemahaman kepada peserta khususnya UMKM tentang cara memasarkan produk secara online dengan memanfaatkan teknologi secara gratis. Pelatihan ini akan memperkenalkan produk yang ditawarkan dalam jangka panjang dibandingkan dengan cara konvensional yang dapat ditawarkan dalam jangka pendek.

Pelatihan yang diberikan kepada masyarakat di Desa Meruya Selatan yang ingin berwirausaha melalui pemanfaatan teknologi untuk meningkatkan efeisiensi pemasaran produk. Hasil pelatihan ini dapat dimanfaatkan untuk meningkatkan daya saing dan pengetahuan masyarakat mengenai pemasaran di era digital sekarang ini.
Profil Penulis

Roy Budiharjo,

Suri Mahrani
Program Studi A kuntansi, Fakultas Ekonomi dan Bisnis, Universitas Mercu Buana Jakarta

\section{Penulis korespondensi:} Roy Budiharjo

email: budiharjo@mercubuana.ac.id

Reviewing Editor

Suryani, IAIN Lhokseumawe, Aceh

Kata Kunci : Pemasaran Online, UMKM

\section{PENDAHULUAN}

Di negara maju, sudah banyak orang yang melakukan pemasaran online atau pemasaran dengan menggunakan internet (internet marketing). Pemasaran online di luar negeri didukung oleh fasilitas yang memadai, seperti akses internet cepat dengan jaringan ADSL, Ebank (bank yang tidak mempunyai cabang offline), dan jasa kurir (pengiriman barang) yang terintegrasi dengan penerimaan paket di convenience store.

Sementara itu di Indonesia, pemasaran online belum mencapai tahap booming seperti di luar negeri. Meskipun akses internet cepat dengan jaringan ADSL, 3G maupun 3,5G sudah mulai dapat dinikmati oleh masyarakat, namun layanan akses internet cepat tersebut masih terbatas pada kota-kota besar saja. Untuk mendukung akses perbankan yang cepat, murah dan mudah, hampir sebagian besar bank di Indonesia telah menyediakan Iayanan internet banking dan SMS banking. Meskipun demikian, produk tersebut adalah merupakan produk bank konvensional, yang membutuhkan biaya administrasi yang cukup tinggi untuk transfer antar bank. Hambatan lain juga terjadi pada penyedia layanan kurir (pengiriman barang), yaitu dengan masih banyaknya kasus paket yang hilang, paket yang sampai tidak tepat waktu, sampai dengan ongkos kirim yang mahal ke daerah terpencil dan daerah Indonesia Timur.

\section{Permasalahan di lapangan}

Walaupun pemasaran online di Indonesia menghadapi banyak hambatan, namun seiring dengan kemajuan teknologi informasi dan teknologi perbankan serta pelayanan jasa kurir, Indonesia diyakini akan mampu mengejar ketertinggalannya dalam bidang pemasaran online dalam beberapa beberapa tahun yang akan datang. Dalam rangka menghadapi era 
booming pemasaran online di Indonesia, para pelaku bisnis dan UKM harus segera memulai pemasaran online.

Seiring dengan semakin banyaknya angka pengangguran di Indonesia, dibutuhkan semakin banyak wirausaha muda yang sanggup membuka lapangan kerja yang baru. Para wirausaha muda ini diharapkan dapat menjadi agent of change dalam memasarkan produk usahanya. Produk tidak hanya dipasarkan secara konvensional, tetapi juga harus dapat dipasarkan secara global menggunakan internet.

\section{Target Capaian}

Peserta diharapkan dapat memiliki pengetahuan yang memadai dalam melakukan pemasaran melalui media online seperti berjualan melal ui Facebook ataupun dalam group WhatsApps (WA). Metode ini merupakan cara yang dapat dilakukan apabila ingin berwirausaha oleh berbagai masyarakat dari sekedar coba-coba berbisnis sampai para pebisnis yang sudah lama menjadi seorang bisnis., karena dengan media jejaring sosial tersebut produk yang akan dijual dapat dipasarkan dengan mudah, murah dan cepat pada sasaran pelanggannya.

\section{MATERI DAN METODE}

Pengabdian masyarakat ini di laksanakan di Perumahan yang terletak di kelurahan di Wilayah sekitar Universitas Mercu Buana dengan melibatkan warga masyarakat disekitarnya sejumlah 20 orang. Pengabdian ini diutamakan untuk para ibu rumah tamgga, wirausaha dan cal on wirausaha karena diharapkan mereka mempunyai kemampuan dalam memasarkan produk secara online. Metode kegiatan yang akan digunakan adalah sebagai berikut:

1. Metode penyuluhan; digunakan untuk menyampaikan materi yang berupa teori.

2. Metode Tanya jawab; digunakan untuk memberikan kesempatan bagi peserla yang belum jelasdalam pemahamannya;

3. MetodeDemonstras; contoh: mengel ola dan merencanakan keuangan keluarga;

4. Melakukan serangkaian test berupa test verbal berupa wawancara serta test tertulis berupa pemberian beberapa pertanyaan yang harus dijawab oleh khalayak sasaran.

\section{Rancangan Evaluasi}

Mengunjungi dan wawancara dengan para peserta 1-2 bulan setelah pelaksanaan pengabdian masyarakat dilakukan.

\section{Rencana D an Jadwal Kerja}

Kegiatan ini rencananya akan dilaksanakan pada:

Hari dan Tanggal : : Minggu, 01 Juni 2019

Waktu :09.00-12.00 WIB

Tempat : : Kelurahan Meruya Selatan 


\section{Pelaksanaan Kegiatan}

\section{HASIL DAN PEMBAHASAN}

Pelaksanaan Pengabdian Masyarakat ini berlangsung pada hari Minggu tanggal 1 Juni 2019 yang bertempat di RT 007 RW 002 Kelurahan Meruya Selatan. Peserta yang dihadiri oleh Ibu - ibu PKK berjumlah 26 orang dari target 30 orang dan pelaksanaan acara berlangsung sesuai jadwal yang telah ditetapkan. Dalam pelaksanaannya peserta diberikan materi modul dan pelatihan. Pada kegiatan tersebut dilaksanakan dalam bentuk pelatihan berupa penyampaian materi.

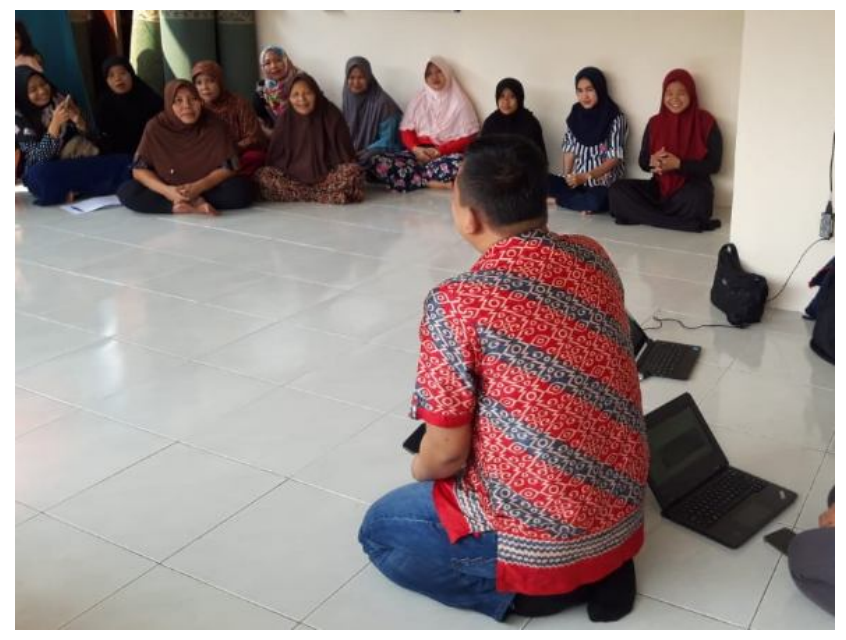

G ambar 1.

Penyampaian materi dan dikusi

\section{Peserta}

1. Target peserta yang ingin dicapai sebanyak 30 orang, sedangkan yang mengikuti kegiatan sebanyak 26 orang

2. Waktu pelaksanaan kegiatan sesuai dengan jadwal yang telah dibuat.

2. Selama acara berlangsung tercipta suasana yang tertib dan aman sehingga kegiatan tersebut dapat berjal an dengan lancar.

3. Para peserta sudah lebih kritis dalam suatu hal yang belum dimengerti.

\section{Langkah-langkah memulai berjualan online:}

1. Menggunakanlah fasilitas gratis dari blog atau jejaring sosial untuk menampung produk jualan. Fotolah dengan menarik, karena produk yang anda tawarkan sangat-sangatlah tergantung dengan hasil foto yang baik.

2. Tata produk yang anda tawarkan dengan baik pada blog tersebut. Misal menggunakan label atau kategori jika produk yang anda jual lebih dari 1 jenis. Kategori/ label akan memudah- kan konsumen mengakses foto produk yang anda tawarkan.

3. Berikan syarat dan prosedur pembelian dengan lengkap. Syarat dan prosedur sangatlah penting.

4. Ada produk yang ready stock dan ada yang menawarkan pre order alias pesan dulu baru dibuat, kayak sepatu atau tas.

5. Pembayaran menggunakan jasa bank apa saja harus dicantumkan (no rek. Diberitahukan kemudian, tidak perlu dimasukkan dalam persyaratan). 
6. Pengiriman produk menggunakan jasa apa. Misal Tiki JNE, atau ekspedisi pengiriman lain. Masukkan juga tarifnya per daerah sehingga yg beli tau tarif ke daerah.

\section{Evaluasi Kegiatan}

Secara keseluruhan, kegiatan tersebut berjalan dengan aman, tertib dan terkendali, sehingga tujuan yang ingin dicapai dapat terlaksana. Setiap panitia melaksanakan tugas sesuai dengan yang diatur oleh ketua pelaksana. Kegiatan tersebut telah berhasil dilaksanakan dengan baik dan sesuai dengan rencana yang ingin dicapai, namun dapat diatasi dengan baik. Selama pelaksanaan acara tersebut tidak terdapat masalah besar yang dapat mengganggu jalannya acara. Respon yang baik peserta tunjukan dengan sikap kooperatif antara karangtaruna dan para instruktur yang membuat suasana pengabdian masyarakat ini berupa pelatihan menjadi lebih bersahabat.

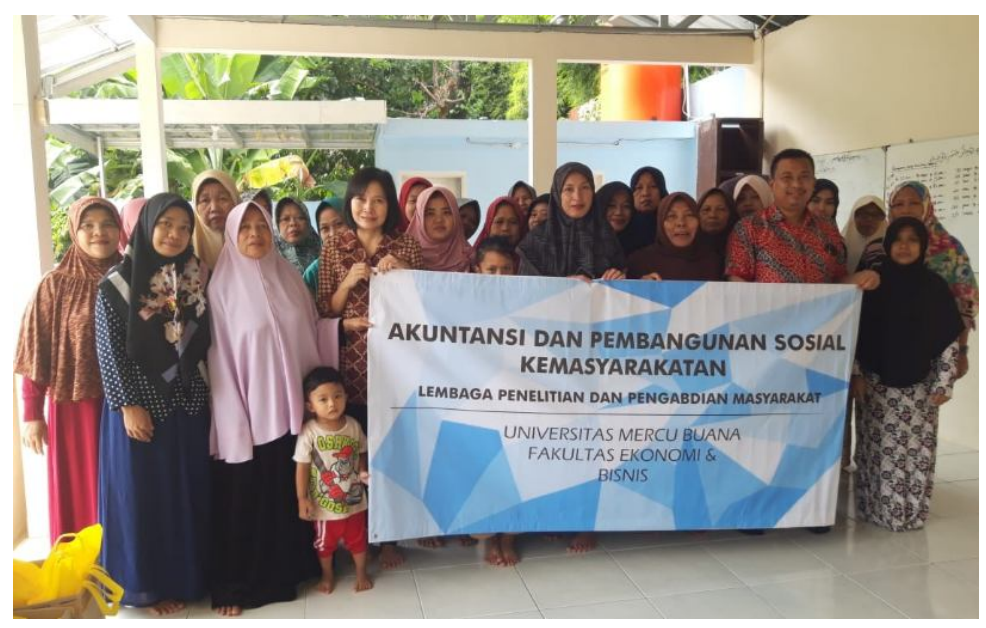

\section{Gambar 2.}

Photo bersama setelah kegiatan

Pelaksanaan kegiatan Pengabdian kepada Masyarakat (PkM) diharapkan dilaksanakan secara rutin dan dapat dilakukan Iebih lama yai tu dal am beberapa pertemuan sehingga lebih terfokus dalam pelatihannya. Kegiatan ini diharapkan dapat meningkatkan kualitas sumber daya manusia.

\section{KESIMPULAN}

\section{Kesimpulan}

Pada dasarnya penjualan online seperti dapat memudahkan kegiatan belanja bagi orang sibuk ataupun bagi orang yang ingin jualan tetapi tidak mempunyai toko. Dengan adanya web blogger atau yang lainnya dapat digunakan sebagai sarana pemasaran dan penjualan yang ampuh, mudah dan murah dalam mempromosikan produk jualannya. Kegiatan ini merupakan langkah awal untuk memberikan pengetahuan mengenai pemasaran kepada masyarakat sehingga mampu memasarkan produknya secara lebih efisien.

\section{Saran kegiatan Lanjutan}

Kegiatan ini merupakan langkah awal yang perlu ditindaklanjuti. Berikutnya masih perlu dilakukan pelaksanaan pelatihan yang secara riil mempraktekkan model pemasaran online dengan melibatkan praktisi lokal untuk memberikan motivasi dan contoh kepada masyarakat. 


\section{REFERENSI}

Kotler, P \& Armstrong, G. (2012), Principles of Marketing, Fourteen Edition, Pearson Education Limited, England.

Mariah, M., \& Nurbaiti, D. (2019). Pengaruh persepsi online store dan offline store pada persepsi nilai dan dampaknya terhadap minat beli pada produk fashion. Jurnal $M$ anajemen Strategi dan A plikasi Bisnis, 2(2), 215-222.

Pujiyanti, S. D., \& Wahdi, A. (2020). Transaksi Bisnis Online dalam Perspektif Islam. SER A M BI: Jurnal Ekonomi M an ajemen dan Bisnis Islam, 2(2), 91-102.

Ramadhan, T., \& Darmo, I. S. (2020). Pemanfaatan Data Pemasaran Digital Dalam Penentuan Lokasi Geografis Terbaik Untuk Penempatan Iklan Produk. Jurnal Manajemen Strategi dan A plikasi Bisnis, 3(1), 51-64.

\section{FUNDING}

Kegiatan ini merupakan bagian dari program Pengabdian Kepada Masyarakat yang di danai oleh Universitas Mercu Buana.

\section{COMPETING INTEREST}

Tidak ada konflik kepentingan untuk diungkapkan.

\section{A bout The A uthors}

Roy Budiharjo, Lawe Anasta, dan Suri Mahrani merupakan dosen di Program Studi Akuntansi, Fakultas Ekonomi dan Bisnis, Universitas Mercu Buana Jakarta 